\title{
Prostatic function in the brush-tailed possum, Trichosurus vulpecula
}

\author{
B. Cook, I. R. McDonald* and W. R. Gibson* \\ Department of Steroid Biochemistry, University of Glasgow, Royal Infirmary, \\ Glasgow G4 OSF, U.K. and \\ *Department of Physiology, Monash University, Clayton, Victoria 3168, Australia
}

\begin{abstract}
Summary. Perspex casts were made of the reproductive tract and the blood vessels supplying the prostate of the brush-tailed possum. The urethra is surrounded by a network of arteries and veins from which a large number of small vessels radiate into the body of the prostate. This complex of vessels might be capable of transferring androgens carried from the epididymis to the urethra into the prostatic parenchyma. Testosterone $5 \alpha$-reductase was of highest specific activity in the epididymis and was more active in the posterior than the central prostate; the two metabolites of testosterone detected were $5 \alpha$-dihydrotestosterone and $5 \alpha$-androstane-3 $3,17 \beta$-diol. In 3 untreated possums in December the mean serum concentrations of testosterone, DHT and androstenedione were $3 \cdot 8,1.9$ and $0.4 \mathrm{ng} / \mathrm{ml}$, respectively. Zinc concentrations (mean \pm s.e.m., $\mathrm{N}=3$ ) were $1.6 \pm 0.1 \mu \mathrm{g} / \mathrm{ml}$ serum, $61 \pm 13 \mu \mathrm{g} / \mathrm{g}$ central prostate, and $13 \pm 2 \mu \mathrm{g} / \mathrm{g}$ posterior prostate. There was a positive correlation between serum testosterone concentration and prostatic weight.
\end{abstract}

\section{Introduction}

The prostate and Cowper's glands are the only accessory sex glands in the reproductive tract of male marsupials (Setchell, 1977). The prostate of the male brush-tailed possum (Trichosurus vulpecula) may reach enormous size, filling the lower abdominal cavity at times of seasonally related sexual activity, and it has been suggested that this increase is essential to provide sufficient vehicle for the adequate transfer of spermatozoa for impregnation of the female (Howarth, 1950; Gilmore, 1969).

Pierrepoint, Davies, Millington \& John (197.5b) have presented evidence that, in the rat and dog, the deferential vein may act as a local transport system for the transfer of androgen from the testis and epididymis to the prostate. Moreover, in the rat, reflux of blood from the deferential vein to the larger prostatic veins can occur in certain circumstances (Lewis \& Moffat, 1975). Such a mechanism in Trichosurus could ensure that the prostate received androgens at much higher concentrations than those in peripheral blood and account for the rapid, up to 10-fold, increase in prostatic weight during breeding periods. Pierrepoint, Davies \& Wilson (1974) pointed out that a direct connection between the rat epididymis and prostate appears to be essential for the functional integrity of the prostate and that this control appears to be unilateral. These authors further suggest that the epididymis may be essential for the local conversion of testosterone to $5 \alpha$-reduced metabolites which appear to be the appropriate steroids for maintenance of prostatic function. The ductus deferens has also been proposed as a local route along which testosterone may normally pass in rams to maintain the function of accessory structures such as the ampulla (Skinner \& Rowson, 1968a, b). We describe here experiments to investigate the nature, and local metabolism, of the androgens secreted by brush-tailed possums and the possibility of a mechanism of direct transfer of androgen from the testis and epididymis to the prostate gland.

\section{Materials and Methods}

Male possums weighing 2-3 kg were trapped in the vicinity of Melbourne and housed indoors under natural photoperiod in large enclosures. They were fed a mixed diet of sheep pellets, fresh fruit, 
carrots, cabbage and sunflower seeds, which is compatible with a healthy breeding colony. Observations were made during November and early December, which is the end of a secondary breeding period (Dunnet, 1964), when prostate glands would be expected to be regressing (Gilmore, 1969).

\section{Biochemical observations}

Six adult males were removed from the colony and housed in individual metabolism cages. They were fed the standard diet ad libitum. Three males were injected i.m. with $2 \mathrm{mg}$ testosterone oenanthate in oil (Primoteston Depot: Schering AG, Berlin) every 2nd day for 14 days in an attempt to stimulate prostatic growth and function. The other three were left untreated for the same period. At the end of this time, the animals were anaesthetized rapidly with ether and within $5 \mathrm{~min}$ of induction a blood sample was taken by cardiac puncture. Each animal was then killed by an overdose of anaesthetic, and the prostate, testes and epididymides were removed, kept on ice and weighed. Samples of central and posterior prostate (Rodger \& Hughes, 1973; Pl. 1, Fig. 1) were weighed and preserved for assay of $5 \alpha$-reductase activity and zinc. Weighed samples of testis and epididymis were taken for assay of $5 \alpha$-reductase activity. The blood samples, collected into polystyrene syringes, were transferred to polypropylene tubes and allowed to clot at $10^{\circ} \mathrm{C}$ for $4 \mathrm{~h}$. The serum was then separated by centrifugation at $1800 \mathrm{~g}$ for $3 \mathrm{~min}$.

Zinc estimation. Samples for zinc analysis were placed in polypropylene containers, with care to avoid contamination with zinc from extraneous sources, and zinc content was measured with a Perkin-Elmer atomic absorption spectrometer.

Androgens. Samples of serum (2-5 ml) were thawed and twice extracted with three times their volume of ether. The extracts for each sample were pooled, evaporated to dryness, taken up in petroleum ether (b.p. $60-80^{\circ} \mathrm{C}$ )-chloroform $(95: 5 \mathrm{v} / \mathrm{v}$ ) and transferred to columns of Lipidex 5000 (Packard Instrument Co. Inc., Illinois, U.S.A.) made up in the same solvent. Each column contained approximately $2.5 \mathrm{~g}$ Lipidex to give a bed $200 \mathrm{~mm}$ high and $7 \mathrm{~mm}$ internal diameter. Fractions containing androstenedione, $5 \alpha$-dihydrotestosterone (DHT) and testosterone were eluted as described by Jänne, Apter \& Vihko (1974) and the steroids were measured by radioimmunoassay. An antiserum raised in sheep against testosterone-3-carboxymethyloxime coupled to bovine serum albumin was used for assay of testosterone and DHT (Cook, Hunter \& Kelly, 1977). The antiserum used to measure androstenedione was a gift from Dr W. P. Collins, King's College Hospital, London, and was raised in rabbits against androstenedione-1 $\alpha$-hemisuccinate coupled to bovine serum albumin. Procedural losses were checked by using standards run with the batch of samples and ranged from 10 to $20 \%$. Final values were corrected for losses on the basis of these standards. The coefficients of variation for the assays did not exceed $12 \%$, and the lowest androgen concentrations that could be determined in serum were about $5 \mathrm{pg} / \mathrm{ml}$.

Testosterone-5a-reductase. The radiometric assay described by Wallace \& Grant (1975a) and Cowan, Cowan, Grant \& Elder (1977) was used with adaptations to suit the tissues under investigation. Weighed tissue was chopped with scissors, dropped into liquid nitrogen and pulverized in a stainless-steel press also cooled in liquid nitrogen. The pulverized tissue was homogenized in an allglass system with buffer $(250 \mathrm{mmol}$ sucrose $/ 1,50 \mathrm{mmol}$ Tris- $\mathrm{HCl} / \mathrm{l}$ and $30 \mathrm{mmol}$ nicotinamide/l), $\mathrm{pH} 7 \cdot 4$, to give a final tissue concentration of $200 \mathrm{mg} / \mathrm{ml}$. This pulverization technique was adopted because the prostatic tissues were too fibrous to be homogenized conventionally. The other tissues were similarly treated to maintain comparability. Paper chromatography (Bush, 1951) with petroleum ether (b.p. $\left.80-100^{\circ} \mathrm{C}\right)$ : benzene:methanol : water $(25: 25: 35: 15$ by vol.) as the solvent system was used to purify $\left[1,2-{ }^{3} \mathrm{H}\right]$ testosterone (Radiochemical Centre, Amersham, Bucks), which was then diluted with unlabelled testosterone to give a final specific activity of $12 \cdot 5 \mathrm{Ci} / \mathrm{mol}$. To each tube $14 \mathrm{nmol}$ of this material and $400 \mathrm{nmol}$ NADPH (Boehringer, Mannheim) were added as substrates. Tissues were assayed in triplicate; each of the triplicate tubes contained a different amount of homogenate equivalent to 10,20 or $200 \mathrm{mg}$ tissue. All samples were made up to a final volume of $1.5 \mathrm{ml}$ with buffer and incubated for $20 \mathrm{~min}$ at $36^{\circ} \mathrm{C}$. The reaction was stopped by adding $2 \mathrm{ml}$ ethanol and rapidly mixing the contents of the tube. At this stage $100 \mu \mathrm{g}$ each of testosterone and DHT were added to act as carriers during subsequent purification. About $0.02 \mu \mathrm{Ci}$ each of $\left[4-{ }^{14} \mathrm{C}\right]$ testosterone and $\left[4-{ }^{14} \mathrm{C}\right]-$ DHT (Radiochemical Centre), which had also been purified in the Bush system described above, 
were added to assess procedural losses radiometrically. To each tube $100 \mu \mathrm{g} 5 \alpha$-androstane- $3 \alpha, 17 \beta$ diol, a possible further metabolite of DHT, were also added, to act both as a carrier during purification and to assess procedural losses. Steroids were extracted with chloroform, acetylated with pyridine-acetic anhydride $(2: 1, \mathrm{v} / \mathrm{v})$ and purified by thin-layer chromatography on alumina (Cowan et al., 1977). The tritium in the acetates of DHT and androstanediol was determined by liquid scintillation spectrometry. Recovery of DHT was assessed from the ${ }^{14} \mathrm{C}$ in the samples, but because $\left[{ }^{14} \mathrm{C}\right.$ ]androstanediol was unavailable, losses of this compound were assessed by measuring the mass of carrier steroid (now a diacetate) in a portion by gas-liquid chromatography. For this, a glass column, $2 \mathrm{~m}$ long and $4 \mathrm{~mm}$ internal diameter, was packed with 3\% SP2100 on Supelcoport 80-100 mesh, and run at $230^{\circ} \mathrm{C}$ with nitrogen as the carrier gas. Solid-state injection was used. Final quantitation was by fiame ionization detection with free androstanediol as internal standard. The tritium present in the products gave a measure of testosterone reduction. Corrections were made for procedural losses and final results were expressed as pmol of metabolite.

After the initial measurements, 4 pooled samples of the DHT fractions and 4 pooled samples of the androstanediol fractions were made from each of the 4 tissues. The DHT (as acetate) was recrystallized to constant isotope ratio after carrier DHT acetate had been added. The pooled samples of androstanediol diacetate were saponified and the chromatographic systems described by Beastall (1975) were used to identify which epimers of androstanediol were present in a sub-sample from each tissue. Only androstane- $3 \alpha, 17 \beta$-diol was found, and following the addition of more carrier the remaining steroid from each of the pools was recrystallized to constant specific activity.

Statistical analyses of the amounts of testosterone reduction, DHT production and androstanediol production were carried out by analysis of variance by using fitted orthogonal coefficients (Steel \& Torrie, 1960).

\section{Anatomical observations}

Two adult males were killed by an overdose of ether. The abdominal aorta and vena cava were cannulated with polythene tubing ( $2 \mathrm{~mm}$ i.d.) directed towards the pelvis and tightly secured with two ligatures. The vascular system distal to these ligatures was flushed out with approximately $200 \mathrm{ml}$ $0.9 \%(\mathrm{w} / \mathrm{v}) \mathrm{NaCl}$ solution containing heparin (approximately $10 \mathrm{i} . \mathrm{u} . / \mathrm{ml}$ ) to remove most of the blood. Polythene cannulae were then inserted and tied into the vasa deferentia and urethra. Perspex monomer (Tensol No. 7 acrylic cement: I.C.I., Australia), with blue colour added for veins, red for arteries and yellow for the reproductive tract, was mixed with hardener and immediately injected into the cannulae. The arteries and veins were injected simultaneously in an attempt to fill both sides of the vascular system evenly. When the vessels were filled with monomer, the vascular cannulae were clamped. The vasa deferentia and urethra were then filled with the yellow monomer. After allowing polymerization to occur at $4^{\circ} \mathrm{C}$ overnight, the body was severed anterior to the cannula, the hind limbs and tail dissected off, and the remainder of the injected preparation was immersed in $30 \% \mathrm{HCl}$ to dissolve the tissues. This took 3-4 days. Final traces of tissue were removed from the acrylic casts of the blood vessels by jets of water from a syringe fitted with a 26-gauge needle.

\section{Results}

\section{Serum androgens and prostatic weight}

Testosterone, DHT and androstenedione were identified in extracts of blood serum from the 3 untreated possums, and the mean ( \pm s.e.m.) concentrations were $3.8 \pm 1.5,1.9 \pm 0.8$ and $0.4 \pm$ $0.2 \mathrm{ng} / \mathrm{ml}$ respectively. The values in two of the testosterone-injected possums were much higher; but those of the other animal were within the range of untreated animals. The relative concentrations of the three androgens were little changed by the testosterone injections (Text-fig. 1). There was a positive correlation $(P<0.05)$ between the serum concentrations of the individual androgens and the weight of the prostate (Text-fig. 1). 


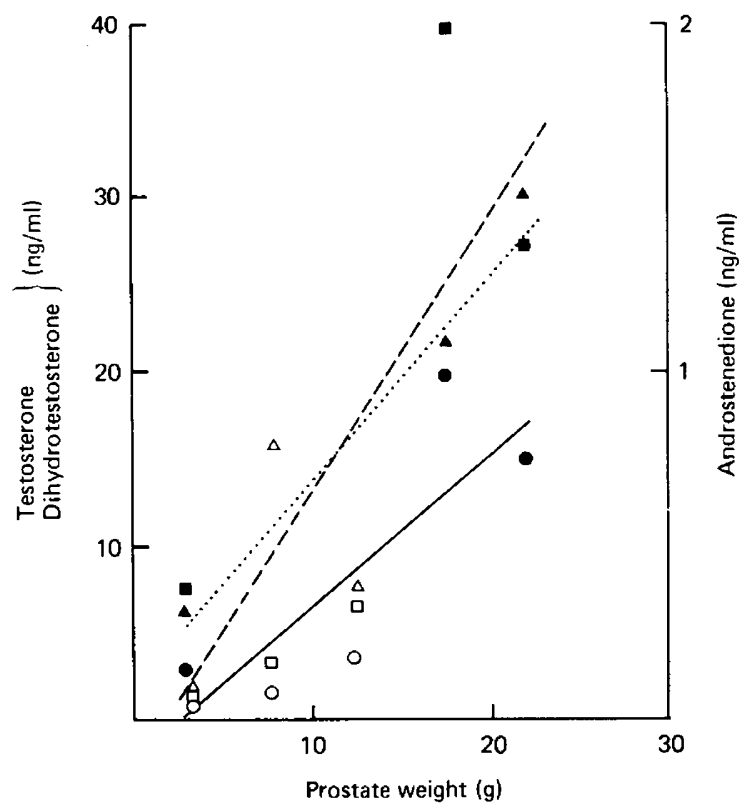

Text-fig. 1. The relationship between prostatic weight and concentrations of androstenedione $(\Delta, \Delta)$, $5 \alpha$-dihydrotestosterone (DHT) $(0, \bullet)$ and testosterone $(\square, \square)$ in peripheral blood serum in brush-tailed possums. Solid symbols $(\Lambda, \bullet, \square)$ indicate values from animals that were injected with testosterone oenanthate (see text). The regressions of steroid concentration on prostatic weight are given by the lines $\cdots$. for androstenedione; -_- for DHT; and --_- for testosterone. The correlation coefficients for steroid concentration and prostate weights are: androstenedione, 0.89 ; DHT, 0.86 ; and testosterone, 0.81 .

\section{Identification of metabolites}

Reduction of the added $\left[{ }^{3} \mathrm{H}\right]$ testosterone to DHT and $5 \alpha$-androstanediol occurred in all the incubated tissues; no other tritiated products were detected. The pooled, incubated material was used to confirm the identity of the separated steroids and adequacy of the assays. Recrystallization of added DHT acetate resulted in less than $10 \%$ irregular variation of isotope ratio through three cycles. By using the technique of Beastall (1975), which permits separation of all the four epimers of $5 \alpha$-androstanediol, the tritium was found to be associated only with $5 \alpha$-androstane-3 $\alpha, 17 \beta$-diol. The specific activity of this material did not change by more than $10 \%$ through three recrystallizations after adding more authentic steroid.

\section{EXPLANATION OF PLATE}

On all figures, the scale mark represents $1 \mathrm{~cm}$; B, bladder; $C$, central prostate; $D$, vas deferens; $N$, neck of bladder; $P$, posterior prostate; $U$, urethra.

Fig. 1. The prostate of the brush-tailed possum in situ. The anterior prostate, which is a small conical zone next to the bladder, is not visible. The vasa deferentia enter the urethra (which the prostate surrounds) immediately below the neck of the bladder. The prostatic blood vessels visible in this figure supply only the membrane that invests the gland.

Fig. 2. A perspex cast of the blood vessels surrounding the prostatic urethra. In this specimen, the urethra was distended by introducing excess plastic. Close to the bladder and within the prostate, the urethral diameter is normally large (about $4 \mathrm{~mm}$ ) but this decreases as the urethra passes towards the posterior prostate (at the bottom of the figure); the distension of this specimen exaggerates the taper. The urethra is surrounded by a complex network of arteries and veins which send branches into the body of the prostate. In this figure, these branches have been shortened to give a better view of the urethral blood vessels.

Fig. 3. A perspex cast of blood vessels radiating into the prostate from the urethral network. Here, the urethra is not distended; the orientation of the specimen is the same as that in Fig. 2, but the preparation is from a smaller gland. 

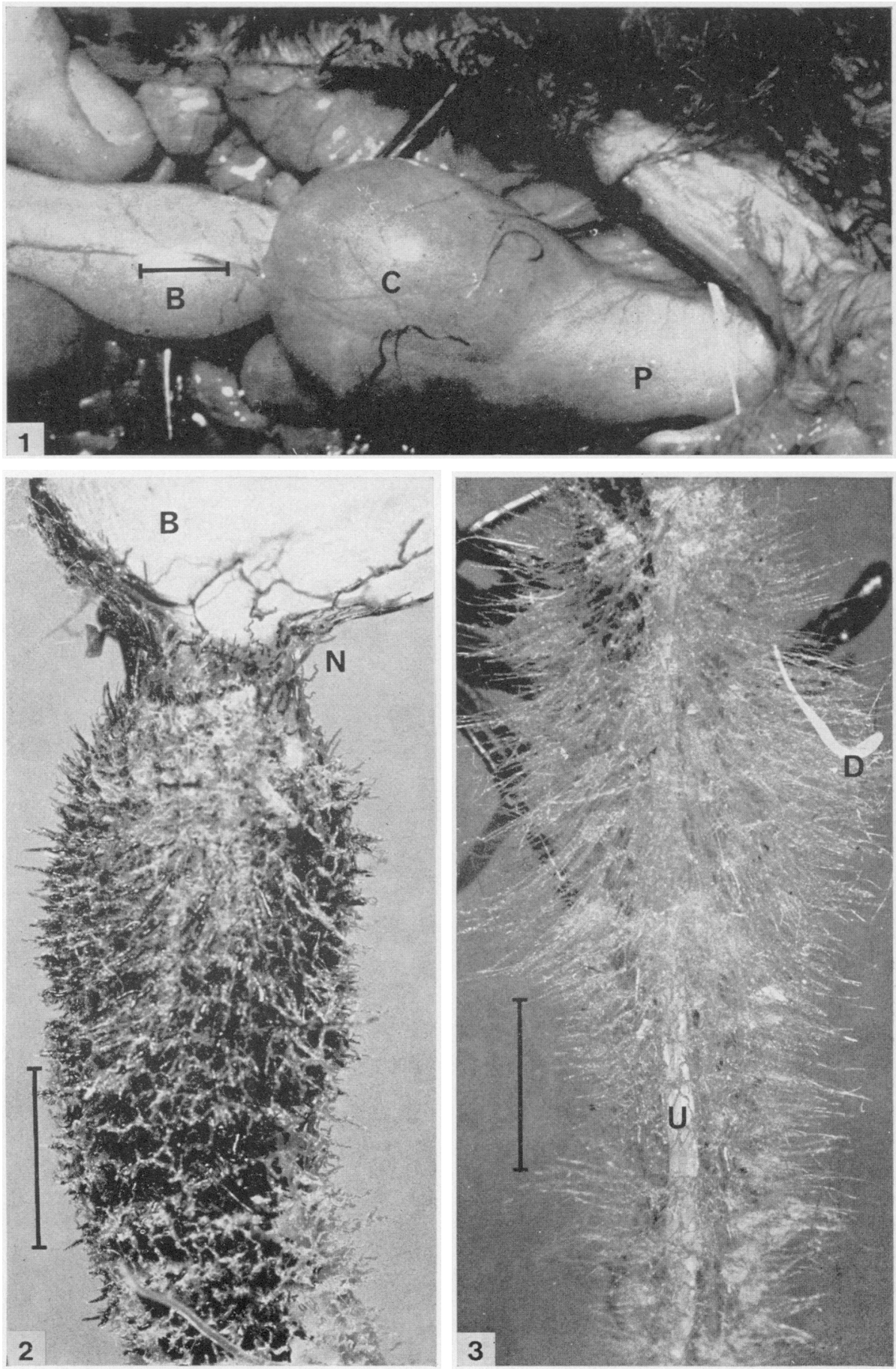

1 furtug p. 372 
Table 1. Total $5 \alpha$-reduced metabolites of testosterone (dihydrotestosterone plus $5 \alpha$-androstanediol) produced by different tissues of the brush-tailed possum during incubation for $20 \mathrm{~min}$ and their examination by analysis of variance

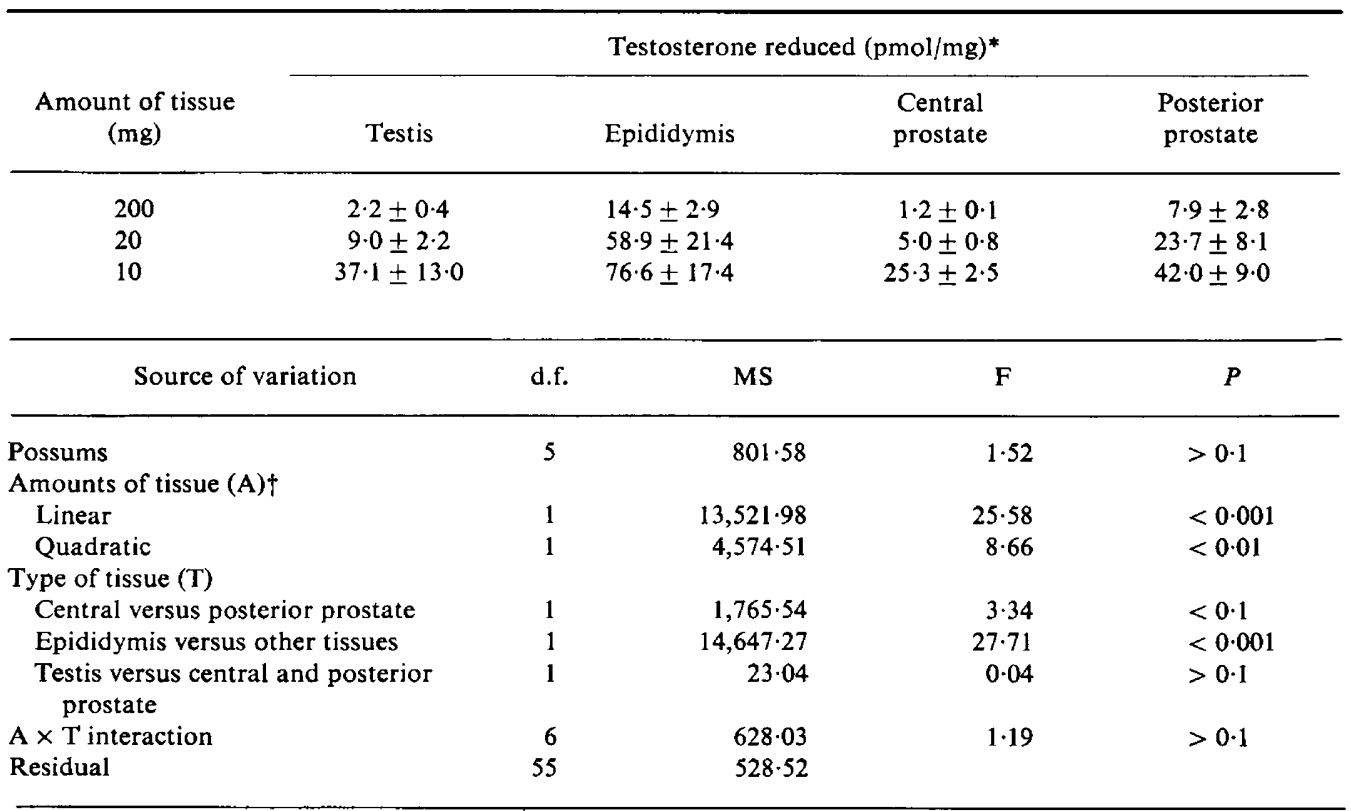

* Each value is the mean ( \pm s.e.m.) for incubated tissues from 6 possums.

† Linear and quadratic components of variance due to 'Amounts of tissue' were found by using the method of Grandage (1958).

\section{Activity of $5 \alpha$-reductase}

The sum of the two testosterone metabolites was used as an index of $5 \alpha$-reductase activity (Table 1). Analysis of variance showed that there were clear differences in activity between organs but not between different possums, i.e. the $5 \alpha$-reductase activity appeared not to be influenced by organ weight or plasma androgen concentration. Analysis of variance of the data from all incubations showed that the greatest $5 \alpha$-reductase activity was in the epididymis $(P<0.001)$, the posterior zone of the prostate had less activity than the epididymis but more than the central prostate $(P<0 \cdot 1)$, and the testis was intermediate in activity between the two prostatic zones. The hierarchy of activities was the same regardless of the amount of tissue incubated (Table 1). The smallest $(10 \mathrm{mg})$ masses of tissue showed much higher specific activity $(P<0.001)$ than did the larger $(20$ and $200 \mathrm{mg})$ masses. The further reduction of testosterone beyond DHT to $5 \alpha$-androstanediol was greatest in the testis, in which the mean androstanediol:DHT ratio was 0.4 , intermediate in the posterior prostate where the ratio was $0 \cdot 2$, and least in the epididymis and central prostate, in which the ratio was $0 \cdot 1$.

\section{Zinc concentrations}

In the 3 untreated possums the mean ( \pm s.e.m.) concentration of zinc in the central zone of the prostate was $61 \pm 13 \mu \mathrm{g} / \mathrm{g}$ wet weight, compared with only $13 \pm 2 \mu \mathrm{g} / \mathrm{g}$ in the posterior zone $(P<0 \cdot 1$, paired $t$ test). The concentration of zinc in the blood serum of 5 possums was $1 \cdot 6 \pm 0 \cdot 1 \mu \mathrm{g} / \mathrm{ml}$.

\section{Blood supply to the prostate}

As in the rat (Pierrepoint, Davies, Lewis \& Moffat, 1975a), the blood supply to the possum prostate arose from a ring of vessels surrounding the neck of the bladder but, unlike the rat, the deferential vessels did not enter this region. An extremely rich network of fine blood vessels arose 
from the vessels at the neck of the bladder and surrounded the prostatic urethra. Fine arteries radiated from this network to supply the prostatic parenchyma. The vas deferens entered the urethra close to the neck of the bladder, and therefore seminal plasma secreted in the duct must pass through the richly vascularized segment of urethra from which the prostatic blood supply emerged (PI. 1, Figs 2 and 3).

\section{Discussion}

The concentration of testosterone in the serum of untreated possums was comparable with that found in man, but that of DHT was approximately 10 times the human value (Ito \& Horton, 1970), which is itself relatively high. This high concentration of DHT in the peripheral blood of untreated possums, the approximately constant ratios of the concentrations of testosterone and its two metabolites observed after testosterone injections (Text-fig. 1), and the high specific activity of $5 \alpha$-reductase in possum sex gland tissues (Table 1), indicate that DHT is an important metabolite of testosterone in this species. There was no evidence to suggest differences in biological activity of the three androgens, because the parallel changes in serum concentrations resulted in equally good correlations between prostatic weight (as an indicator of activity) and individual androgen concentration.

The marked decrease of $5 \alpha$-reductase specific activity with increasing mass of tissue incubated (Table 1) was probably caused by the depletion of substrate by the larger tissue masses. The largest mass of epididymal tissue utilized nearly $3 \mathrm{nmol}$ of the $14 \mathrm{nmol}\left[{ }^{3} \mathrm{H}\right]$ testosterone added. This loss of more than $20 \%$ of the initial amount of substrate must have reduced the reaction rate. Incubations with the least amount of tissue would therefore be expected to give the closest approximation to the initial reaction rate. The posterior zone of the possum prostate contains much more stromal tissue than the central zone (Carrodus \& Bolliger, 1939) and hence $5 \alpha$-reductase activity could be associated more with stromal than secretory tissue. Cowan et al. (1977) have presented convincing evidence that the same association occurs in human prostatic tissue.

The concentration of zinc in the possum prostate is of the same order as that reported for man, dog and cat (Whitmore, 1963), but its distribution, as in the rat (Gunn, Gould, Ginori \& Morse, 1955), is not uniform in the various zones. The distribution of zinc in the possum prostate is similar to that of $N$-acetylglucosamine (Rodger \& White, 1976) which is a major seminal component in Trichosurus (Rodger \& White, 1974). The serum concentration of zinc in possums is not significantly higher than that in man (McBean, Smith, Berne \& Halsted, 1974), dog (Smith, 1974) and rat (Luécke, Ruskan \& Baltzer, 1970). Wallace \& Grant (1975b) showed that added zinc inhibited testosterone $5 \alpha$-reductase activity in hyperplastic prostates of man. In the possum prostate, the higher $5 \alpha$-reductase activity occurred in the zone which had the lower zinc concentration.

The anatomical observations suggest the possibility of direct transfer of androgens from the fluid contents of the urethra to the prostatic parenchyma via the rich vascular plexus surrounding the prostatic urethra distal to the point of entry of the ductus deferens. Spermatorrhoea is commonly found in breeding and non-breeding possums (Bolliger, 1942) and is evidence for a continuous flow of material from the epididymis to the urethra. The urine of one of the possums used in the present investigation was examined microscopically and contained $6 \times 10^{5}$ spermatozoa $/ \mathrm{ml}$. Testosterone has been found at a concentration of $100 \mathrm{ng} / \mathrm{ml}$ in plasma from the spermatic vein of Trichosurus vulpecula (Carrick \& Cox, 1973) and, although the androgen content of possum seminal fiuid is not known, it seems likely that it would also be high. The high $5 \alpha$-reductase activity of the epididymis suggests that, if a direct mechanism of transfer did operate, DHT could be the agent causing prostatic hypertrophy.

We thank Dr B. E. James for his expert advice and practical help with the zinc determinations; Jill Duncan and Anne Kelly for help with the experiments and steroid assays; and Diana Harrison and Jill Poynton for their photography. Financial support was provided by the Carnegie Trust for the Universities of Scotland and Grant No. 068/3168 from the Australian Research Grants Committee. 


\section{References}

Beastall, G.H. (1975) Testosterone metabolism in superfused human hyperplastic prostate. Biochem. Soc. Trans. 3, 677-680.

Bolliger, A. (1942) Spermatorrhoea in marsupials, with special reference to the action of sex hormones on spermatogenesis of Trichosurus vulpecula.J. Proc. R. Soc. N.S.W. 76, 86-92.

BusH, I.E. (1951) Methods of paper chromatography of steroids applicable to the study of steroids in mammalian blood and tissues. Biochem. J. 50, 370-378.

Carrick, F.N. \& Cox, R.I. (1973) Testosterone concentrations in the spermatic vein plasma of marsupials. J. Reprod. Fert. 32, 338-339.

Carrodus, A. \& Bolliger, A. (1939) The effect of oestrogenic hormone on the prostate of the marsupial Trichosurus vulpecula. Med.J. Aust. 2, 633-641.

CoOK, B., HưNTER, R.H.F. \& Kelly, A.S.L. (1977) Steroid-binding proteins in follicular fluid and peripheral plasma from pigs, cows and sheep. $J$. Reprod. Fert. 51, 65-71.

Cowan, R.A., Cowan, S.K., Grant, J.K. \& Elder, H.Y. (1977) Biochemical investigations of separated epithelium and stroma from benign hyperplastic prostatic tissue. J. Endocr. 74, 111-120.

DunNeT, G.M. (1964) A field study of local populations of the brush-tailed possum Trichosurus vulpecula in Eastern Australia. Proc. zool. Soc. Lond. 142, 665695.

GiLmore, D.P. (1969) Seasonal reproductive periodicity in the male Australian brush-tailed possum (Trichosurus vulpecula). J. Zool., Lond. 157, 75-98.

Grandage, A. (1958) Orthogonal coefficients for unequal intervals. Biometrics 14, 287-289.

GunN, S.A., Gould, T.C., Ginori, S.S. \& Morse, J.G. (1955) Selective uptake of $\mathrm{Zn}^{65}$ by dorsolateral prostate of rat. Proc. Soc. exp. Biol. Med. 88, 556558.

HowarTh, V.S. (1950) Experimental prostatectomy in a marsupial (Trichosurus vulpecula). Med. J. Aust. 2, 325-330.

Ito, T. \& Horton, R. (1970) Dihydrostestosterone in human peripheral plasma. J. clin. Endocr. Metab. 31, 362-368.

JÄNNE, O., APTER, D. \& VIHKO, R. (1974) Assay of testosterone, progesterone and 17 $\alpha$-hydroxyprogesterone in human plasma by radioimmunoassay after separation on hydroxyalkoxypropyl Sephadex. J. Steroid Biochem. 5, 155-162.

Lewis, M.H. \& Moffat, D.B. (1975) The venous drainage of the accessory reproductive organs of the rat with special reference to prostatic metabolism. $J$. Reprod. Fert. 42, 497-502.

Lú́cke, R.W., Ruskan, B.E. \& Baltzer, B.V. (1970) The zinc content of blood serum and bone as indices of dietary zinc adequacy in the rat. In Trace Element Metabolism in Animals, pp. 471-473. Ed. C. F. Mills. Livingstone, Edinburgh.
McBean, L.D., Smith, J.C., Jr, Berne, B.H. \& Halsted, J.A. (1974) Serum zinc, and alpha $a_{2}$-macroglobulin concentration in myocardial infarction, decubitus ulcer, multiple myeloma, prostatic carcinoma, Down's syndrome and nephrotic syndrome. Clin. chim. Acta 50, 43-51.

Pierrepoint, C.G., Davies, P. \& Wilson, D.W. (1974) The role of the epididymis and ductus deferens in the direct and unilateral control of the prostate and seminal vesicles of the rat. J. Reprod. Fert. 41, 413-423.

Pierrepoint, C.G., Davies, P., Lewis, M.H. \& Moffat, D.B. (1975a) Examination of the hypothesis that a direct control system exists for the prostate and seminal vesicles. J. Reprod. Fert. 44, 395-409.

Pierrepoint, C.G., Davies, P., Millington, D. \& JoHN, B.T. (1975b) Evidence that the deferential vein acts as a local transport system for androgen in the rat and the dog. J. Reprod. Fert. 43, 293-303.

Rodger, J.C. \& Hughes, R.L. (1973) Studies of the accessory glands of male marsupials. Aust. J. Zool. 21, 303-320.

Rodger, J.C. \& White, I.G. (1974) Free N-acetylglucosamine in marsupial semen. $J$. Reprod. Fert. 39, 383-386.

Rodger, J.C. \& White, I.G. (1976) Source of seminal $\mathrm{N}$-acetylglucosamine in Australian marsupials and further studies of free sugars of the marsupial prostate gland. J. Reprod. Fert. 46, 467-469.

SETCHELl, B.P. (1977) Reproduction in male marsupials. In The Biology of Marsupials, pp. 411-457. Eds B. Stonehouse \& D. Gilmore. Macmillan, London.

Skinner, J.D. \& Rowson, L.E.A. (1968a) Some effects of unilateral cryptorchism and vasectomy on sexual development of the pubescent ram and bull. $J$. Endocr. 42, 311-321.

SKINNER, J.D. \& Rowson, L.E.A. (1968b) Effects of testosterone injected unilaterally down the vas deferens on the accessory glands of the ram. $J$. Endocr. 42, 355-356.

Smith, E. (1974) Comments on zinc in the canine prostate. In Normal and Abnormal Growth of the Prostate, pp. 530-533. Ed. M. Goland. Thomas, Springfield, Illinois.

Steel, R.G.D. \& Torrie, J.H. (1960) Principles and Procedures of Statistics. McGraw-Hill, New York.

Wallace, A.M. \& Grant, J.K. (1975a) The testosterone $5 \alpha$-reductase of human hyperplastic prostate. $J$. Endocr. 67, 10P-11P.

Wallace, A.M. \& Grant, J.K. (1975b) Effect of zinc on androgen metabolism in the human hyperplastic prostate. Biochem. Soc. Trans. 3, 540-542.

Whitmore, W.F., Jr (1963) Comments on zinc in the human and canine prostates. In Biology of the Prostate and Related Tissues, pp. 337-340. Natn. Cancer Inst. Monograph No. 12. 